\title{
The Importance Of Educational Level For Farmer's Upward Social Mobility In Wringinpitu Village
}

\author{
Paramitha, N. A. ${ }^{1}$, Supriyadi ${ }^{2}$, Zuber, A. ${ }^{3}$ \\ ${ }^{1}$ Post graduate student, Department Sociology, Sebelas Maret University, Indonesia \\ ${ }^{2,3}$ Department Sociology, Sebelas Maret University, Indonesia \\ Corresponding email: paramitha.na@student.uns.ac.id
}

\begin{abstract}
Education influences upward movement in vertical social mobility. With scholars not returning to villages, upward social mobility in a farmer's society slows down. The research was conducted from September 2017 until April 2018 in Wringinpitu village, Tegaldlimo sub-district, Banyuwangi district with the aim of determining upward social mobility of farmers in Wringinpitu village. Upward social mobility is determined by the differences in a farmer's life, before and after planting oranges, land ownership, wealth, and social position in a society. The research uses a qualitative case study design with data collected through observation, documentation, and in-depth interviews. The informants were selected based on a purposive sampling method. The data was then validated by triangulation and analyzed using the interactive model. The results has shown that the factors affecting upward social mobility was not only due to higher education levels but also from opportunities, family background, and social capital. Scholarly farmers achieve the highest social position while farmers with only junior high school background having the lowest social position. The less educated farmers are less able to absorb information and make innovations. Scholarly farmers are more successful and become role models for other farmers. Farmer with higher education are able to achieve higher vertical social mobility and vice versa. The results of the research propose that educational institutions should educate and motivate scholars to return to their villages as agents of change.
\end{abstract}

Keywords: higher education; orange farmer; upward social mobility

DOI: $10.20961 /$ ijpte.v\%vi\%i.25864

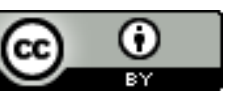

Except where otherwise noted, content on this site is licensed under a Creative Commons Attribution 4.0 International License. 


\section{INTRODUCTION}

Villages are commonly known as traditional areas, low educated populations, and poor living. While this may seem right, it is not entirely true. Nowadays there are many examples of modern developed villages. The Wringinpitu village is an example of such modern villages. Agriculture is a livelihood for many villagers. Farmers in Wringinpitu formerly planted rice but since 2000 farmers started grow oranges. Since then, the income of farmers has increased rapidly and in turn affects their welfare. Farmers can now move from one position to another position in society, a move called upward social mobility. Farmer who get higher education and higher income can move to an upper social strata in society. The increase in one's social status is a testament of his successful business.

Agricultural development in a rural area is generally influenced by the level of knowledge of the farmers. The knowledge and skills of farmers tend to be low (Rais and Sheoran, 2015; Pardede, 2005: 79) and farmers have little information about markets that cause farmers being manipulated by traders (Magesa, et al., 2014). Referring to Suryana (2012: 175), fruit farmers spread the knowledge of conventional fruit farming from one to another. The fact is that there has been no government representatives who are specifically tasked in handling the citrus agribusiness (Badan Litbang Pertanian, 2005: 16).

During this time, farmers in Wringinpitu village mainly carry out their agricultural related business by self-learning. Though there are some farmers who are highly educated and have the skills in cultivation and becoming role models for the other farmers in Wringinpitu village. Farmers share information on experimental results, creations, innovations in agricultural input, how to plant and care the plants, and others.

After planting oranges, farmers in Wringinpitu village experienced significant economic improvements. The increase in economy enables farmers to better pay for their children education fees. Villagers are increasingly aware of the importance of education. Farm children are no longer just an asset for manual labor employment in agriculture business, with the children being sent to high school and even to universities in cities.

Educational institutions provide knowledge and skill provisions for students finding employment. Normally, after graduating from university, scholars choose to work as office employees. Unemployed groups in an educated workforce, due to most scholars willingly choose to be unemployed and wait for other opportunities to work in offices that provide a fixed salary (Effendi, 1993: 23). Others are willing to work for odd jobs or work as manual laborers as long as they can live in the city. Nowadays, less scholars return to their villages even though they are needed as an agent of change in their village. To make a change, villagers need a pioneer or a role model. The fewer numbers of scholars who want to return to their village is one of the causes of the slowness in social mobility in the village.

Research by Deary, et. al. (2005) showed that, in Scotland, education is the main factor influencing upward social mobility. Other factors affecting upward social mobility is height, childhood IQ, and their father's social class. Research by 
Hellier (2017) develops an approach which shows that higher education is a key factor of low intergenerational mobility at the top and low educational efficiency in France. Another study from China, Bian (2002) found that serious scholarly works in social mobility research: status attainment, career mobility, and social networks in occupational processes, show stability and change in the once politicized social mobility regime in China. Status attainment and career mobility influence a person's opportunities for upward social mobility on positional power and qualifications.

Previous research discuss factors affecting mobility. Compared to previous research, this research will try to analyze mobility, especially upward social mobility sociologically. We try to analyze factors affecting upward vertical social mobility in Wringinpitu village based on the farmer's educational level with a qualitative method. Education is one the ways to achieve a better social position in society. Sociology understands social mobility based on changes in status and social position in the hierarchy of society (Pattinasarany, 2016: 31). Social mobility occurring in Wringinpitu farmers is an upward vertical social mobility. Although many farmers experience upward vertical social mobility, their mobility can be differentiated by their educational level. This research aims to determine the upward social mobility of farmers in Wringinpitu village.

\section{LITERATURE REVIEW}

\section{Social Mobility}

Sociology defines social mobility as a change in social status or social position of individuals, families, or groups in the hierarchy of society (Pattinasarany, 2016: 31). Vertical social mobility is a movement of someone from another social group, higher or lower (Nasution, 1999: 35), whereas horizontal social mobility is a movement of someone from one to another social position in the same level (Pattinasarany, 2016: 35). Someone who performs social mobility by moving from lower position to the higher position called upward mobility and the movement from higher position to lower position called downward mobility (Pattinasarany, 2016: 35). In vertical social mobility, someone's status will change, for example someone attains high education and becomes rich means he moves upward in the social hierarchy (Nazimuddin, 2015).

Referring to Pattinasarany (2016: 40-45), there are four factors affecting social mobility. The four factors are education, opportunity, family background, and social capital.

\section{Education}

The focus of development is not only physical capital (land, technology, capital, and natural resources), but also human capital (human resources) (Effendi, 1993: $6,31)$. High productivity can be achieved by improving the quality of human resources through increased education (Effendi, 1993: 6, 15). Education is the most widely analyzed factor in various social studies to see its effect on social mobility. Education is seen as a social escalator by functional structural thinkers. Education not only provides knowledge, but also the ability of individuals to be able to achieve higher social position in society. 
Education does play a mediating role between the class of origin and the class of destinations, but influences the influence of education on social mobility (Nunn, et al., 2007). The relationship between higher education and upward social mobility in Indonesia is a social-economics inequality, geography, and cultural inequality (Arifin, 2017). Someone who attains high education or skill will receive economic and non-economic rewards such as social status from the society as compensation for their works (Pattinasarany, 2016: 41-42).

\section{Opportunity}

Opportunity means the availability of a chance for someone to achieve a better life for himself and his family. In the context of social mobility, the definition of opportunity is the level at which one's income and social class is determined by their skill and ambition, and not at all by things inherited or obtained from their parents. The inherited positions have become less and less because the person's heir cannot always give the same chair to his son or daughter (Nazimuddin, 2015).

\section{Family's background}

Family's background influences one's ability to achieve success in work. In Britain, the material environment of the home was of less importance in differentiating between the successful and the unsuccessful child than differences in the size of the family and in the education, attitudes and ambitions of the parents (Banks, 1973: 66). According to Banks (1973: 69), "poverty can make a parent less willing to keep a child at school; can make it difficult for him to afford books... It is for this reason that it is sometimes suggested that school achievement should be related not to isolated factors in the environment but to family life as a whole".

\section{Social Capital}

In many countries, studies conducted has linked social capital and social mobility. In addition to social capital, human capital also affects social mobility. In contemporary British society, whilst continuing to enjoy bonding social capital built on social ties with similar status positions, they also enjoy bridging social capital with people in different status positions, which is denied to those in the disadvantaged groups (Li, et. al., 2008). Both formal and informal aspects of social capital are conducive to generalized trust and age makes no difference to generalized trust when the more powerful socio-cultural factors are taken into account (Li, et. al., 2008).

\section{Education for Social Mobility}

Formal education and non-formal education play an important role in social mobility because better educated people can gain higher social status and higher positions in society (Nazimuddin, 2015). The association between education and social mobility depends on the extent in which formal educational qualifications is necessary for the requirement in positions of high status (Banks,1973: 36). A School's function is to prepare the children not only for a job, but also provide basic skills, open up opportunities and improve their future, help solve social related problems, and so forth (Nasution, 1999: 14-17). According to Banks (1973: 61), formal educational institutions have taken over not only the teaching of specific skills, but much of the normative training from families as well. 
Everything taught in school plays an important role as an "agent of change" to make social change.

According to Nasution (1999: 39-41), elementary school and even high school education nowadays has almost no effect in social mobility. The requirement for today's social mobility is higher education. But even though many of today's villagers are educated up to university, the problem is that many of the scholars do not return to their village but rather choose to settle in the city instead.

Education is important for social mobility. Teachers in educational institutions have to play the role in encouraging students to achieve higher achievements. Schools can open opportunities to improve the status of children from lower classes. In addition to providing knowledge for students, teachers should motivate students to return to their village. Top down model of government policies usually do not work when applied in villages. Those who have better understanding for the needs in rural development are the villagers themselves. It is very important for scholars to return to their villages and become agents of change. Educated scholars can help villagers make innovations to improve their welfare.

\section{Scholars as Agent of Change}

The Indonesian government understands the importance of scholar's role in rural development. As an obvious example is the Sarjana Membangun Desa (SMD) program. SMD is a program from the Ministry of Agriculture which aims to empower farmer groups by placing scholars to participate, assist, and educate farmer groups throughout Indonesia. Scholars in this program serve as pioneers in community empowerment programs as well as to improve the economy of the community. SMD in general is defined as a form of scholar's awareness in which the scholars after having completed their education, return to the villages, where they build and develop local potentials together with the community. Through this form of awareness, the Indonesian government expects more scholars to participate in developing villages which turn strengthen the village's economy. An example of SMD can be seen through its role in empowering and improving the economy of Gunungrejo Makmur breeders group, successfully achieving a good level of economic resilience (Nasrudin, et al., 2017).

\section{RESEARCH DESIGN}

This research uses a case study approach due to the Wringinpitu village orange farmer's case being rather unusual or unique. Wringinpitu village is located in Tegaldlimo sub-district, Banyuwangi district, East Java province, Indonesia. The research begins with a pre-eliminary study. Pre-eleminary study was conducted through the researcher's correspondence with key informants since 2016 and conducted observation in Wringinpitu village in September 2017. Further research conducted in February to April 2018.

The purposive sampling technique with the maximum variation strategy was used to obtain informants. The purpose of using maximum variation sampling is to documenting the diversity of individuals or places based on specific features (Creswell, 2014: 220). The main informants totaled twelve people are farmer. 
Additional informant also added to complement the data. They are government and farmer's family that amounted to eight people.

Data collection was done through field observation, in-depth interviews, and documentation of various documents that can support the research. The data validated by cross-checking data with triangulation. We cross-checking data from observation, data from documentation, and data from in-depth interviews with those informants. Validated data were analyzed with interactive model from Miles and Huberman. According to Miles and Huberman (1992), the interactive model of data analysis includes data collection, data reduction, data presentation, and conclusion/ verification.

\section{RESEARCH FINDING AND IMPLICATION}

\section{Condition of Wringinpitu Village}

Wringinpitu village is located in Tegaldlimo sub-district, Banyuwangi district. Tegaldlimo is the widest sub-district in Banyuwangi district and is well known as a farming area. However, compared to other areas such as Bangorejo, Purwoharjo, Pesanggaran, and Siliragung that have already developed orange farms, Wringinpitu village had only developed orange farms since the year 2000. Previously, farmers in Wringinpitu village had planted rice but after seeing the success of orange farmers from other areas, Wringinpitu's farmers soon followed.

Wringinpitu village is located in a suitable area for agriculture. The agricultural land in Wringinpitu village comprises of 340 hectares of wet fields and 250 hectares of dry fields. Wringinpitu village consists of three hamlets, namely Bayatrejo, Ringin Asri, and Ringin Anom. The area of Bayatrejo is very wide with the hamlet divided into the north and south. Ringin Asri, Ringin Anom, and South Bayatrejo are agricultural areas, while North Bayatrejo has developed into a brick production area.

The population of Wringinpitu numbered at 9013 people, with 4357 men and 4656 women. Villagers who graduated from elementary school numbered at 1307 people, junior high school numbered at 462 people, senior high school numbered at 751 people, and those with a diploma degree and undergraduate numbered at 30 and 479 people respectively. Wringinpitu villagers mostly work in agriculture with farmers numbered at 1659 people and farm laborers numbered at 3792 people.

\section{Characteristics of Informants}

The informants consisted of twelve Wringinpitu villagers who work as orange farmers or as agricultural laborers in the orange agribusiness sector. Additional informants consisted of four people from farming families and four government employees.

The following table contain the characteristics of informants. 
Table 1. The characteristics of informants

\begin{tabular}{|c|c|c|c|}
\hline Name & Education & Occupation & Other Informations \\
\hline A & $\begin{array}{l}\text { Undergraduate } \\
\text { degree }\end{array}$ & $\begin{array}{l}\text { Farmer and agricultural } \\
\text { shop owner }\end{array}$ & $\begin{array}{l}\text { Taking care of the distribution of } \\
\text { subsidized fertilizer; pioneer of dragon } \\
\text { fruit farmer in Wringinpitu; become a role } \\
\text { model for other farmers }\end{array}$ \\
\hline B & $\begin{array}{l}\text { Undergraduate } \\
\text { degree }\end{array}$ & Farmer and trader & Ever supply oranges to supermarket \\
\hline $\mathrm{C}$ & $\begin{array}{l}\text { Undergraduate } \\
\text { degree }\end{array}$ & Farmer & Sell his own orange harvest to the city \\
\hline $\mathrm{D}$ & Senior High School & Farmer & $\begin{array}{l}\text { Chairman of farmer group; teaches other } \\
\text { farmer making organic fertilizer }\end{array}$ \\
\hline $\mathrm{E}$ & Senior High School & Farmer and trader & - \\
\hline $\mathrm{F}$ & Senior High School & Farmer and small trader & - \\
\hline $\mathrm{G}$ & Senior High School & Farmer and trader & Rent his orange farm \\
\hline $\mathrm{H}$ & Senior High School & Farmer and small trader & $\begin{array}{l}\text { Working alone and working for other } \\
\text { traders }\end{array}$ \\
\hline $\mathrm{I}$ & Senior High School & $\begin{array}{l}\text { Farmer and government } \\
\text { employee }\end{array}$ & - \\
\hline $\mathrm{J}$ & Junior High School & $\begin{array}{l}\text { Farmer and chicken } \\
\text { breeder }\end{array}$ & - \\
\hline $\mathrm{K}$ & Junior High School & Farm labor & Working on her aunt's farm \\
\hline $\mathrm{L}$ & Junior High School & Farm labor & - \\
\hline
\end{tabular}

Based on Table 1 above, there are twelve main informants. Three farmers with undergraduate degrees, six senior high school educated farmers, and three farmers with junior high school education.

\section{Vertical Social Mobility Based on Farmer Education Level}

The farmers in Wringinpitu village stated that there is actually a farmer's group in Wringinpitu village, but it is not active. The Wringinpitu village body also states that farmer groups in the village are groups for rice and chili farming. Farmer groups for orange farming have yet to exist. Information from the employees of the Department of Agriculture also states that government counseling is only intended for farmer groups with government licenses. The farmers also state that counseling for orange farmers does not come from the government, but from producers of agricultural input. These statements show that the government has no role in orange farming in Wringinpitu village.

During these times, farmers get information from other farmers who have been proven successful. These successful farmers can be friends or family. The orange farming information then grew from one farmer to another. Cross-information indicates that farmers are getting information from agricultural shop owners. For example if the farmers needed to ask about a particular disease the agricultural shop owner will tell them how to correctly handle it and give the proper remedy.

Farmer A who is a bachelor degree of agriculture, is able to access agricultural books and the internet, so he becomes a pioneer in innovation by planting dragon fruit. Farmer A tells other farmers to plant the profitable dragon fruit. Farmer A also sells subsidized fertilizer at his agricultural shop. He also acts as a steward of subsidized fertilizer.

Some farmers in Wringinpitu village are also traders. Farmer B is able to plant rice, melon, orange, and dragon fruit. Farmer $\mathrm{B}$ is a bachelor degree of 
economics. He can make calculations in agriculture, so he dares to trade fruits to cities, out of the island, and to supermarkets. The ability of farmer B in trading is obtained through self-learning and learns from his cousin's experience. His cousin is also a trader. Farmer $\mathrm{C}$ is also a scholar. Formerly, he once opened a fertilizer shop, but the shop was discontinued. Farmer $\mathrm{C}$ is able to innovate by selling his own crops out of village. The ability of farmer $\mathrm{C}$ is supported by social capital kinship with market traders outside the village.

Senior high school educated farmers are less able to innovate when compared to undergraduate degree farmers. Education in high schools only provides general knowledge, not specific knowledge as in college. However, there is a farmer who is a graduate from senior high school of agriculture. Armed with a background of agricultural education and a great interest continuing his father's work as a farmer, allows farmer D to become a farmer with upward vertical social mobility. Farmer D becomes the chairman of the farmer's group. He is able to make compost and teach it to other farmers. He also tried to sell his own crops out of village, but fell victim to fraud by traders in the market.

Another senior high school farmer is farmer E. He also works as a big trader. $\mathrm{He}$ only buys fruit from other traders and did not trade with farmers. He sells the oranges to the city and even out of the island. Farmer F was an orange farmer, but was less successful and now has begun to plant dragon fruit. Farmer F used to be a small trader and now his business has been growing up. He has employees and owns a pickup truck. Farmer $G$ is an orange farmer, but his orange trees were infected by a virus. Eventually he rented out his orange farm to other farmers. For now, farmer $\mathrm{G}$ is more focused on his trading business even though he is often cheated by various parties.

Farmer $\mathrm{H}$ was originally a fruit trader. After seeing the successfulness of orange farmers, farmer $\mathrm{H}$ started to plant oranges. Farmer $\mathrm{H}$ is a small trader who works for himself, but sometimes he works for other traders. Farmer $\mathrm{H}$ has a wife who graduated from elementary school and a daughter who graduated from senior high school. His wife did not have any idea about farming and trading. But, her daughter has some information about farming and trading. Farmer I is a farmer who also works as government employee. Farmer I assisted his wife in taking care of his orange farm. His wife is a senior high school graduate. Farmer I and his wife got farming information from their friends from other areas that have proven successful. They are very selective in choosing traders when selling oranges. Farmer I also rented out his orange farm in time of need.

Farmers $\mathbf{J}$ with junior high education is quite a successful farmer. In addition to farming, he is also a chicken breeder. Information about agriculture was obtained through farmer $\mathrm{A}$, his brother-in-law. Farmer $\mathrm{J}$ is also a pioneer in planting dragon fruit following the footsteps of farmer A. Both other junior high school educated farmers are farmer K and farmer L. Farmer K works as a farm labor on her aunt's orange farm. She once tried to plant dragon fruit, but failed. Farmer L is also a farm laborer. Farmer L did not dare to rent a land because he has no capital.

From the research findings above, we argue that all of farmers achieve upward vertical social mobility since they had worked in the orange agribusiness sector. However, their social mobility can be differentiated by their educational level. 
Scholarly farmers are able to achieve high social position in society compared to senior high school farmers and junior high school farmers. The social position of senior high school farmers are lower than scholarly farmers, but higher than junior high school farmers. However, there is a senior high school farmer who is able to become a leader figure for the other farmers because he has a background in agricultural education. In general, junior high school farmers have lower social position than scholarly farmers and senior high school farmers. However, there is a junior high school farmer with a social mobility equivalent to the high school farmers because he can double his income and has family relationship with successful scholarly farmer.

\section{Implication of Factors Affecting Social Mobility}

As discussed above, there are four factors affecting social mobility according to Pattinasarany. These factors are educations, opportunity, one's family background, and social capital. Farmers with higher education can perform higher vertical social mobility than farmers with lower education. A farmer with a wife with senior high school education can help look after the farm and help sell the crops. While those with a wife with only elementary school education do not know much about agriculture.

In the other hand, opportunity also affects the farmer's social mobility. Farmers who have additional occupation such as an agricultural shop owner, a trader, a government employee, or a chicken breeder have the opportunity to earn more income. Farmers who inherit land from their parents or able to buy farmland by themselves and also have the opportunity to cultivate and manage their own land. Farm laborers usually have no land, so they do not have the opportunity to become a land owner due to expensive farmlands in Wringinpitu village.

Family background is also important for social mobility. Rich parents indicates a farmer born with high social position in society. If a farmer has rich parents, he may inherit a large farm and can attain higher education, and vice versa. Farmers who have a successful family member can learn and can get information from their family.

The last factor is social capital. Social capital is also important in affecting social mobility. Farmers who have bonds with successful farmer are able to get information and become successful. They are then able to move to a higher social position in society.

\section{CONCLUSION}

Social mobility is not only affected by education, but also by factors such as opportunity, family background, and social capital. Even a farmer with only a junior high school education can achieve the same levels of social mobility with a senior high school educated farmer because he has the opportunity, family background, and social capital that can help his social position move upward in the society. Compared to the other three factors, education is essential to achieve upward vertical social mobility. In general, scholarly farmers can achieve higher social position than other farmers. While farmers with senior high school education achieve lower social position than scholarly farmers and farmers with 
junior high school education achieve the lowest social position. Even senior high school farmer can become a role model for other farmer because he has the agricultural education background. This research shows that education is important for social mobility. We suggest educational institutions to educate and motivate scholars to return to their villages as an agent of change since those who understand about the village are the villagers themselves.

\section{REFERENCES}

Arifin, M. H. (2017). The Role of Higher Education in Promoting Social Mobility in Indonesia. European Journal of Multidisciplinary Studies Vol. 6, No.1, pp. 233-241.

Badan Penelitian dan Pengembangan Pertanian. (2005). Prospek dan Arah Pengembangan Agribisnis Jeruk. Jakarta: Departemen Pertanian.

Banks, O. (1973). The Sociology of Education - 2nd Edition. London: B. T. Batsford Ltd.

Bian, Y. (2002). Chinese Social Stratification and Social Mobility. Annual Review of Sociology, 28, pp. 91-116.

Creswell, J. W. (2014). Penelitian Kualitatif dan Desain Riset: Memilih di Antara Lima Pendekatan (3th Edition). Yogyakarta: Pustaka Pelajar.

Deary, I. J., Taylor, M. D., Hart, C. L., et. al. (2005). Intergenerational Social Mobility and Mid-Life Status Attainment: Influences of Childhood Intelligence, Childhood Social Factors, and Education. Intelligence, 33 (5): pp. 455-472.

Effendi, T. N. (1993). Sumber Daya Manusia, Peluang Kerja dan Kemiskinan. Yogyakarta: Tiara Wacana Yogya.

Hellier, J. (2017). Stratified Higher Education,Social Mobility at the Top and Efficiency: The case of the French 'Grandes Écoles'. Munich Personal RePEc Archive (MPRA) Paper No. 76724.

Li, Y., Savage, M., and Warde, A. (2008). Social Mobility and Social Capital in Contemporary Britain. The British Journal of Sociology, Vol. 59 (3), pp. 391411.

Magesa, M. M., Michael, K., and Ko, J. (2014). Access to Agricultural Market Information by Rural Farmers in Tanzania. International Journal of Information and Communication Technology Research (ICT), Vol. 4, No. 7.

Miles, M. B. and Huberman, A. M. (1992). Analisis Data Kualitatif: Buku Sumber Tentang Metode-Metode Baru. Jakarta: UI Press.

Nasrudin, Martono, E., and Subejo. (2017). Peran Sarjana Membangun Desa (SMD) dalam Peningkatan Ekonomi Masyarakat dan Implikasinya terhadap Ketahanan Ekonomi Masyarakat (Studi pada Kelompok Peternak Gunungrejo Makmur, Kabupaten Lamongan - Jawa Timur). Jurnal Ketahanan Nasional Vol. 23, No. 3, pp. 280-299. 
Nasution, S. (1999). Sosiologi Pendidikan. Bumi Aksara: Jakarta.

Nazimuddin, SK. (2015). Social Mobility and Role of Education in Promoting Social Mobility. International Journal of Scientific Engineering and Research (IJSER), Vol. 3 Issue 7, pp. 176-179.

Nunn, A., Johnson, S., Monro, S., Bickerstaffe, T., and Kelsey, S. (2007). Factors Influencing Social Mobility. Research Report No. 450 - University of Huddersfield. Norwich: Her Majesty's Stationery Office.

Pardede, E. (2005). Pasca Panen dalam Industri Pertanian. In A. E. Yustika (Ed.), Menjinakkan Liberalisme: Revitalisasi Sektor Pertanian dan Kehutanan (pp. 69-84). Yogyakarta: Pustaka Pelajar.

Pattinasarany, I. R. I. (2016). Stratifikasi dan Mobilitas Sosial. Jakarta: Yayasan Pustaka Obor Indonesia.

Rais M. and Sheoran A. (2015). Scope of Supply Chain Management in Fruits and Vegetables in India. Journal of Food Processing \& Technology, Volume 6: 427, Issue 3.

Suryana, A. (2012). Pasar Minggu Tempo Doeloe: Dinamika Sosial Ekonomi Petani Buah 1921-1966. Jakarta: LIPI Press. 
